due to adhesions as a result of mesh being in contact with viscera are unknown. This contrasts with the low long term recurrence rate of less than $0 \cdot 5-2 \%$, minimal complications, and no deaths after many thousands of elective open repairs in unselected patients reported from many centres. If comparative trials are to be carried out then it is important that local anaesthesia is used for the open repair. Payne et al, ${ }^{3}$ Brooks, ${ }^{4}$ and Rudkin and Maddern' have done so, and the latter two papers favoured the open mesh technique.

Cost effectiveness must be considered. Taylor and Loosemore report on 700 laparoscopic procedures. Laparoscopic disposables cost up to about $£ 450$ a case, so $£ 315000$ would be required. Disposables for a mesh repair are $£ 35$ and would thus amount to $£ 24500$ for 700 repairs. This difference in costs cannot be justified.

Training surgeons in the laparoscopic technique is associated with a long learning curve and extra indirect costs. There are about 2500 general surgeons in England and Wales. I have taught experienced general surgeons the mesh techniques in a day.

Brooks concluded that the open mesh repair (with local anaesthesia) is a "minimally invasive procedure, is appropriate for the greatest number of patients, is the least expensive and has the fewest short- and long-term complications." ${ }_{4}$ Already three major hospitals in California have banned the laparoscopic hernia operation.

\section{J NOTARAS}

London Hernia Centre,

London NW6 2QA

1 Taylor RS, Loosemore TM. Keyhole surgery. BM7 1995;310: 1605. (17 June.)

2 Phillips EH, Aregui M, Carroll BJ, Corbitt J, Crafton WB, Fallas MJ, et al. Incidence of complications following laparoscopic hernioplasty. Surg Endosc 1995;9:16-21.

3 Payne JH Jr, Grininger LM, Izawa MT, Podoll EF, Lindahl PJ, Balfour J. Laparoscopic or open inguinal herniorrhaphy? A randomised prospective trial. Arch Surg 1994;129:973-81.

4 Brooks DC. A prospective comparison of laparoscopic and tension-free open herniorrhaphy. Arch Surg 1994;129:361-6.

5 Rudkin GE, Maddern GJ. Peri-operative outcome for day-case laparoscopic and open inguinal hernia repair. Anaesthesia 1995;50:586-9.

\section{Pyridoxine supplements in the carpal tunnel syndrome}

EDITOR,-I confess to having started the hare that led to megadoses of pyridoxine being given in the carpal tunnel syndrome.' Karl Folkers visited Newcastle some 30 years ago, and when told of my recent finding that aspartate aminotransferase in necropsy tissues was only about half saturated with the coenzyme, pyridoxal phosphate, he jumped to the obvious conclusion that the subjects had been deficient in vitamin B-6. Obvious, but false. In human tissue, ${ }^{2}$ rabbit tissue, ${ }^{3}$ and rat tissue (my unpublished observations) the enzyme is well saturated, but in dead or infarcted tissue the coenzyme saturation falls progressively (the rate depends on temperature and tissue-liver $>$ heart $>$ skeletal muscle) while the total content of holoenzyme plus apoenzyme changes little for many hours, even at $37^{\circ} \mathrm{C}$ (my unpublished observations). This fall in saturation happens in intact, dead or damaged tissue, not in tissue extracts: it is not due to simple physicochemical dissociation of what is an extremely stable enzyme. Whatever the mechanism-and several plausible mechanisms still survive experimental inquiry-this kind of coenzyme desaturation does not reflect the vitamin B-6 nutritional status.

The coenzyme desaturation found in plasma and red cells is likely to be due largely or wholly to processes related to the above. There is no detectable free pyridoxal phosphate in plasma ${ }^{4}$ since the coenzyme binds to macromolecules. At the least, then, doubt attaches to the existing supposed biochemical indicators of vitamin B-6 deficiency, so that megadoses of pyridoxine cannot be justified by use of these indicators. Also, the doses discussed by Peter J Lewis ${ }^{1}$ are 50 to 1000 times the usual recommended daily allowances, which may themselves be exaggerated for reasons connected with the experimental facts cited above.

This is not to say that megadoses of pyridoxine do not work: that can be established empirically, independent of virus B-6 status. It seems most unlikely, however, that the patients concerned were ever vitamin deficient.

Finally, isn't it odd to see a complementary physician recommending enormous doses of an industrially made chemical?

\section{T R C BOYDE}

London W1H 3PJ

1 Lewis PJ. Pain in the hand and wrist. BMf 1995;310:1534. (10

June.)
2 Hollaar L, Jansen PY, van der Laarse A, Dijkshoorn NJ, Bogers AJ, Huysmans HA. Pyridoxal-5'-phosphate-induced stimulation of aspartate aminotransferase and its isoenzymes in lation of aspartate aminotransferase and its isoenzymes in
human myocardial biopsies and autopsies. Clin Chim Acta 1984;139:47-53.

3 De Waal A, le Roux S, Potgieter GM, Barnard HC, Schoombie EM. Changes in activation of aspartate aminotransferase by pyridoxal-5'-phosphate after experimental liver damage in rabbits. Clin Chim Acta 1982;122:395-401.

4 Papineni VLR. Physical status of mitochondrial aspartate aminotransferase in serum and the role of $\alpha_{2}$-macroglobulin in its clearance. Hong Kong: University of Hong Kong, 1993. (PhD thesis.)

\section{Professional performance bill}

Will result in doctors being suspended from register

EDrToR,-The bill going through parliament dealing with revision of the powers of the Genera Medical Council contains a clause that vitally affects all hospital doctors and doctors employed by health authorities. Clause 1.9 of the bill proposes that any doctor referred to the council and whom the council intends to investigate and bring before its disciplinary committee should temporarily lose his or her registration. Whether innocent or guilty, the doctor would become criminally liable if he or she continued to practise as a doctor. There are no time limits on this temporary erasure from the register.

It would be easy for any malevolent health authority or health trust to $\log$ a complaint. On receipt of a complaint from a health authority the General Medical Council's disciplinary committee is almost duty bound to order an investigation and a disciplinary hearing (one can easily visualise the outcry if a hearing was denied to a complaining health authority); the erasure would then be enacted. Suspension from the register, no matter how brief and irrespective of the reason, would enable a health authority or trust to dismiss that doctor, whose livelihood is then gone. In the past several doctors have been dismissed while temporarily suspended from the register. Usually these temporary suspensions have been for a year or so. But there is nothing to stop a determined health authority from using this process to get rid of someone whom it does not like, and there is nothing in law that a doctor will be able to do to stop it.

All this arises from clause 1.9 of the new bill. Every doctor should write to his or her member of parliament to stop the injustice of penalising doctors merely on the grounds of suspicion, before any guilt has been determined. A person used to be regarded as innocent until proved guilty, and only the guilty were punished. Apparently not any more.

JACOBS

Chairman PJ TOMLIN

Study Group on Suspensions, Honorary secretary

Wormingford, Colchester CO6 3AH

\section{Chairman of BMA council's reply}

EDITOR,-The BMA has expressed support for the new professional performance procedures and commends their objectives: to protect the public, to be remedial rather than disciplinary, and to cover doctors in all types of practices. We have several concerns about the implications of the legislation, one of which is the protection of employment rights. This has been brought to the attention of members of parliament during the progress of the bill, and we will continue to raise it during future stages of the bill in both houses. The BMA is also pursuing this issue, and others, with the Department of Health and the General Medical Council.

The intention of the legislation is that new procedures will be designed to assess a doctor's knowledge, skills, and attitudes in practice and provide remedial measures, rather than disciplinary ones, to address any deficiencies through retraining.

Clause 1 , to which $\mathrm{H}$ Jacobs and $\mathrm{P} \mathrm{J}$ Tomlin refer, relates to the new professional performance procedures and not the existing disciplinary procedures. A doctor's suspension from the register would come into effect only once the new screening and assessment procedures had taken place and then only if the new committee on professional performance thought it an appropriate course of action. Subsection (9) states that while a person's registration is suspended "he shall be treated as not being registered in the register notwithstanding that his name still appears in it."

With respect to security of employment, the bill provides that suspension of registration shall not terminate any appointment in the public service. This brings the professional performance procedure into line with the existing health procedure. Although the suspension of registration does not terminate the contract, the BMA is concerned that trusts may take independent action to terminate a doctor's contract while he or she is participating in the performance procedures: a trust might wish to avoid paying the doctor's salary and the retraining costs. This would be punitive to the doctor concerned, which is not the intention of the bill.

The BMA is seeking to ensure that the Department of Health makes arrangements whereby the services of a doctor are retained until he or she has completed the remedial procedures and is able to return to medical practice.

A W MACARA

BMA House, Chairman, BMA counci

London WC1H 9JP

\section{Luring the vocationally trained back}

\section{Register of non-principals could help}

EdrTor,-I welcome Maureen Baker and colleagues' attempt to study the increasing group of doctors who are vocationally trained in general practice but not currently practising as principals. ${ }^{1}$ Many members of the Medical Women's Federation find themselves in this position for the reasons mentioned by the authors. We have already discussed with representatives of the General Medical Services Committee the possibility of setting up a register of "non-principals" working in general practice. This would have at least two advantages in addition to those mentioned by the authors. Firstly, difficulty in gaining access to continuing medical eduction is a major problem at present. Doctors who were registered could receive details of relevant educational courses and remain on mailing lists for medical newspapers and information about new drugs. Secondly, democratic representation would become feasible and could 